\title{
Prejudice, Discrimination and Racism - an ethical viewpoint
}

\author{
Russell D'Souza ${ }^{1}$, Avinash De Sousa ${ }^{2}$ \\ ${ }^{1}$ Director and Head, Asia-Pacific UNESCO Chair in Bioethics, Haifa. \\ ${ }^{2}$ Consultant Psychiatrist and Research Associate, Department of Psychiatry, Lokmanya Tilak \\ Municipal Medical College, Mumbai. \\ Corresponding Author: Russell D'Souza \\ E-mail: russell.f.dsouza@gmail.com
} Prejudice, Discrimnation and Racism are important concepts from the point of view of both social
psychology and bioethics. The following editorial looks at these constructs from a deeper and
ethical perspective.
The General Conference of the United Nations Educational, Scientific and Cultural Organization, meeting at Paris at its twentieth session, from 24 October to 28 November 1978 . Whereas it is stated in the Preamble to the Constitution of UNESCO, adopted on 16 November 1945, that "the great and terrible war which has now ended was a war made possible by the denial of the democratic principles of the dignity, equality and mutual respect of men, and by the propagation, in their place, through ignorance and prejudice, of the doctrine of the inequality of men and races", and whereas, according to Article 1 of the said Constitution, the purpose of UNESCO "is to contribute to peace and security by promoting collaboration among the nations through education, science and culture in order to further universal respect for justice, for the rule of law and for the human rights and fundamental freedoms which are affirmed for the peoples of the world, without distinction of race, sex, language or religion, by the Charter of the United Nations" [1].

Recognizing that, more than three decades after the founding of UNESCO, these principles are just as significant as they were when they were embodied in its Constitution.

The Declaration follows the structure of the Universal Declaration of Human Rights, with a preamble followed by eleven articles viz [1].

Article 1 declares that discrimination on the basis of race, color or ethnicity is "an offence to human dignity" and condemns it as a violation of the principles underlying the United Nations Charter, a violation of human rights and a threat to peace and security [1].

Article 2 calls on states, institutions, groups and individuals not to discriminate on the basis of race in human rights. It calls on states to end support for discrimination, and to take affirmative action where necessary to correct it.

Article 3 calls for particular efforts to end racial discrimination in civil rights, housing, employment, education, and calls for everyone to have free access to public places and services regardless of race.

Article 4 calls on states to review policies and repeal laws which discriminate on the basis of race. Article 5 calls for an end to racial segregation and apartheid.

Article 6 calls for an end to racial discrimination in political rights, in particular the right to vote and stand for public office.

Article 7 declares that everyone has the right to equality before the law and to equal justice before the law regardless of race. It calls for everyone to have an effective remedy, enforceable through the courts, for harm suffered through racial discrimination.

Article 8 calls for education to promote tolerance and racial understanding.

Article 9 condemns propaganda and organizations based on the idea of racial supremacism. It calls for incitements to racial violence, or hate speech to be criminalized, and for racist organizations to be outlawed. 
Article 10 calls on the United Nations to study the causes of racial discrimination so as to better combat it.

Article 11 calls on every state to promote respect of fundamental human rights and the principles of this declaration and the Universal Declaration of Human Rights (UDHR).

As a declaration rather than a treaty, the document is non-binding.

\section{Definitions of key terms}

- Prejudice: Prejudice is an unjustified or incorrect attitude (usually negative) towards an individual based solely on the individual's membership of a social group. For example, a person may hold prejudiced views towards a certain race or gender etc. (e.g. sexist) [2].

- Discrimination: Discrimination is the behavior or actions, usually negative, towards an individual or group of people, especially on the basis of sex/race/social class, etc. The relationship between prejudice and racial discrimination is suggested to be 'circular'; meaning one leads to the other [3].

Prejudice refers to thoughts and attitudes a person holds toward a group of people while Discrimination refers to actual actions against such a group. Anti-discrimination laws exist to prevent discriminatory actions against any group of people. A prejudiced person may not act on their attitude. Therefore, someone can be prejudiced towards a certain group but not discriminate against them. Prejudice includes all three components of an attitude (affective, behavioral and cognitive) while Discrimination just involves behaviour [4].

Our prejudices and discriminations are shaped by our attitudes. Attitudes are shaped by the ABC triad theory which is made up of the following - [5]

Affective component: this involves a person's feelings / emotions about the attitude object. For example: "I am scared of spiders".

Behavioral (or conative) component: the way the attitude we have influences on how we act or behave. For example: "I will avoid spiders and scream if I see one".

Cognitive component: this involves a person's belief / knowledge about an attitude object. For example: "I believe spiders are dangerous".

One of the underlying assumptions about the link between attitudes and behavior is that of consistency. This means that we often or usually expect the behavior of a person to be consistent with the attitudes that they hold. This is called the principle of consistency. The Principle of Consistency reflects the idea that people are rational and attempt to behave rationally at all times and that a person's behaviour should be consistent with their attitude(s).

\section{Authoritarian Personality and Prejudice}

Adorno and others proposed that prejudice is the result of an individual's personality type. They piloted and developed a questionnaire, which they called the F-scale ( $\mathrm{F}$ for fascism). Adorno argued that deep-seated personality traits predisposed some individuals to be highly sensitive to totalitarian and antidemocratic ideas. Therefore, they were prone to be highly prejudicial [6].

Clinical studies indicated that individuals with a very strict upbringing by critical and harsh parents were most likely to develop an authoritarian personality. Adorno believed that this was because the individual in question was not able to express hostility towards their parents (for being strict and critical). Consequently, the person would then displace this aggression / hostility onto safer targets, namely those who are weaker, such as ethnic minorities. These personalities were hostile to those who are of inferior status, but obedient to people with high status and were fairly rigid in their opinions and beliefs. They were conventional and upheld traditional values. Adorno concluded that people with authoritarian personalities were more likely to categorize people into "us" and "them" groups, seeing their own group as superior [6].

\section{Realistic Conflict Theory and Prejudice}

Muzafer Sherif is a famous social psychologist important to the psychological understanding of groups and its members. His main contribution is known as Realistic Conflict Theory, and accounts for group conflict, negative prejudices, and stereotypes as being the result of competition 
between groups for desired resources. Sherif validated his theory in one his most famous experiments, The Robber's Cave [7].

In the Robbers Cave field experiment, 22 white, 11-year-old boys were sent to a special remote summer camp in Oklahoma, Robbers Cave State Park. The boys developed an attachment to their groups throughout the first week of the camp by doing various activities together like hiking, swimming, etc. The boys chose names for their groups, The Eagles and The Rattlers. During a four-day series of competitions between the groups prejudice began to become apparent between the two groups (both physical and verbal). During the subsequent two-day cooling off period, the boys listed features of the two groups. The boys tended to characterize their own in-group in very favorable terms, and the other out-group in very unfavorable terms. Sherif then attempted to reduce the prejudice, or inter-group conflict, shown by each group. However, simply increasing the contact of the two groups only made the situation worse. Alternatively forcing the groups to work together to reach common goals, eased prejudice and tension among the groups. This experiment confirmed Sherif's realistic conflict theory (also called realistic group conflict theory), the idea that group conflict can result from competition over resources [7].

The simplest explanation for this conflict is competition. Assign strangers to groups, throw the groups into competition, stir the pot, and soon there is conflict. There is a lot of evidence that when people compete for scarce resources (e.g. jobs, land etc.) there is a rise in hostility between groups.

A stereotype is a fixed, over generalized belief about a particular group or class of people. For example, a "hells angel" biker dresses in leather. One advantage of a stereotype is that it enables us to respond rapidly to situations because we may have had a similar experience before. One disadvantage is that it makes us ignore differences between individuals; therefore, we think things about people that might not be true (i.e. make over generalizations) [8].

Tajfel proposed that the groups (e.g. social class, family, football team etc.) which people belonged to were an important source of pride and self-esteem. Groups give a sense of social identity: a sense of belonging to the social world. People divided the world into "them" and "us" based through a process of social categorization (i.e. we put people into social groups). Henri Tajfel proposed that stereotyping (i.e. putting people into groups and categories) is based on a normal cognitive process: the tendency to group things together. In doing so we tend to exaggerate - [9]

1. The differences between groups

2. The similarities of things in the same group.

This is known as in-group (us) and out-group (them). The central hypothesis of social identity theory is that group members of an in-group will seek to find negative aspects of an out-group, thus enhancing their self-image.

Stereotyping goes hand in hand with Prejudice. When we stereotype people, we attribute a series of traits to them based on the one trait that signals their membership in a particular group. Common contemporary stereotypes are that Asians are hardworking and studious, Hispanics are macho, and that librarians are introverts. By definition, stereotypes are limiting and disregard people's individuality. They also lend themselves to negative and derogatory assumptions. When that happens the stereotype blends into prejudice [10].

The tendency to classify one's experience into categories is a fundamental and universal aspect of human cognition. We create concepts in order to make sense of the endless complexity we encounter in our environment. This is a necessary part of human thought, allowing for processing information efficiently and quickly. In social categorization, we place people into categories. People also reflexively distinguish members of in-groups (groups of which the subject is a member) from members of out-groups. Furthermore, people tend to evaluate out-groups more negatively than in-groups. In this way, Social Categories easily lend themselves to stereotypes in general and to Negative stereotypes in particular [11].

\section{Racism}

As prejudice and racism have caused enormous suffering across history, it is very important to try to understand how they work. Prejudice and racism both refer to a negative view of one group of people based solely on their membership in that group. Racism is a specific form of prejudice, 
involving prejudicial attitudes or behavior towards members of an ethnic group. The definition of race is somewhat variable but commonly refers to an ethnic group originating on a specific continent, such as people of African, European, or Asian descent [12].

\section{Reducing Social Prejudice}

Gordon Allport introduced the intergroup-contact hypothesis. Intergroup contact under positive conditions can reduce social prejudice. The necessary conditions include cooperation towards shared goals, equal status between groups, and the support of local authorities and cultural norms. Research has supported these ideas. In a 2003 review, Stephen Wright and Donald Taylor noted the effectiveness of identification with a super-ordinate group. Different groups can come together as part of one overarching group - example Being as part of one community or of a common humanity. Positive emotional experiences with members of different groups can also reduce negative stereotypes. Having close friends from different groups is especially effective [13].

There may be several reasons for this - [14]

First, it is near impossible to hold onto a simplistic, negative stereotype of someone you know well. Secondly, a close relationship promotes identification with the other person and of the groups they belong to. The conclusion is that your relationships with other people become part of who you are. This is referred to as including the other in the self, a notion introduced by Stephen Wright and colleagues.

\section{REFERENCES}

1. Morsink J. The Universal Declaration of Human Rights: origins, drafting, and intent. University of Pennsylvania Press; 1999.

2. Dovidio JF, Gaertner SL. Prejudice, discrimination, and racism. Academic Press; 1986.

3. Kite ME, Whitley Jr BE. Psychology of prejudice and discrimination. Psychology Press; 2016.

4. Thornicroft G, Rose D, Kassam A, Sartorius N. Stigma: ignorance, prejudice or discrimination?. Br J Psychiatry 2007;190(3):192-3.

5. Yılmaz Ç, Altun SA, Olkun S. Factors affecting students' attidude towards Math: ABC theory and its reflection on practice. Proc Soc Behav Sci 2010;2(2):4502-6.

6. Adorno T, Frenkel-Brenswik E, Levinson DJ, Sanford RN. The authoritarian personality. Verso Books; 2019.

7. Sherif M. In Common Predicament: Social Psychology of Intergroup Conflict and Cooperation: The Robbers' Cave Experiment. Norman: University of Oklahoma Book Exchange. 1966.

8. Cox WT, Abramson LY, Devine PG, Hollon SD. Stereotypes, prejudice, and depression: The integrated perspective. Perspect Psychol Sci 2012;7(5):427-49.

9. Tajfel H, Tajfel H. Stereotypes. Race 1963;5(2):3-14.

10. Blair IV. The malleability of automatic stereotypes and prejudice. Personal Soc Psychol Rev 2002;6(3):242-61.

11. Stangor C. Stereotypes and prejudice: Essential readings. Psychology Press; 2000.

12. Miles R, Brown M. Racism. Psychology Press; 2003.

13. Rutland A, Killen M. A developmental science approach to reducing prejudice and social exclusion: Intergroup processes, social-cognitive development, and moral reasoning. Soc Issues Policy Rev 2015;9(1):121-54.

14. Levy SR. Reducing prejudice: Lessons from social-cognitive factors underlying perceiver differences in prejudice. J Soc Issues 1999;55(4):745-65.

Acknowledgements - Nil

Source of Funding - Nil

Conflict of Interest - Nil 